Research article

Open Access

\title{
Short- and long-term effects of anti-CD20 treatment on B cell ontogeny in bone marrow of patients with rheumatoid arthritis
}

\author{
Maria Rehnberg, Sylvie Amu, Andrej Tarkowski, Maria I Bokarewa and Mikael Brisslert
}

\author{
Department of Rheumatology and Inflammation Research, Sahlgrenska Academy at University of Gothenburg, Guldhedsgatan $10 \mathrm{~A}, 41346$ \\ Gothenburg, Sweden \\ Corresponding author: Mikael Brisslert, mikael.brisslert@rheuma.gu.se
}

Received: 10 Mar 2009 Revisions requested: 20 Apr 2009 Revisions received: 29 Jul 2009 Accepted: 17 Aug 2009 Published: 17 Aug 2009

Arthritis Research \& Therapy 2009, 11:R123 (doi:10.1186/ar2789)

This article is online at: http://arthritis-research.com/content/11/4/R123

(C) 2009 Rehnberg et al.; licensee BioMed Central Ltd.

This is an open access article distributed under the terms of the Creative Commons Attribution License (http://creativecommons.org/licenses/by/2.0), which permits unrestricted use, distribution, and reproduction in any medium, provided the original work is properly cited.

\begin{abstract}
Introduction In the present study we evaluated changes in the $B$ cell phenotype in peripheral blood and bone marrow (BM) of patients with rheumatoid arthritis (RA) following anti-CD20 treatment using rituximab.

Methods Blood and BM samples were obtained from 37 patients with RA prior to rituximab treatment. Ten of these patients were resampled 1 month following rituximab, 14 patients after 3 months and the remaining 13 patients were included in the long-term follow up. B cell populations were characterized by CD27/lgD/CD38/CD24 expression.

Results One and three months following rituximab BM retained up to $30 \%$ of B cells while circulation was totally depleted of B cells. Analysis of the remaining BM B cells showed prevalence of immature and/or transitional B cells (CD38++CD24++) and

CD27+lgD- memory cells, while $\lg \mathrm{D}^{+}$cells were completely depleted. A significant reduction of $\mathrm{CD} 27^{+}$cells in BM and in circulation was observed long after rituximab treatment (mean 22 months), while levels of naive B cells in BM and in circulation were increased. The levels of rheumatoid factor decline after rituximab treatment but returned to baseline levels at the time of retreatment.

Conclusions Anti-CD20 treatment achieves a depletion of lgD ${ }^{+}$ $B$ cells shortly after the treatment. At the long term follow up, a reduction of $C D 27+B$ cells was observed in blood and $B M$. The prolonged inability to up-regulate CD27 may inhibit the renewal of memory B cells. This reduction of CD27+ B cells does not prevent autoantibody production suggesting that mechanisms regulating the formation of auto reactive clones are not disrupted by rituximab.
\end{abstract}

\section{Introduction}

$B$ cells are important players in the pathogenesis of rheumatoid arthritis (RA) $[1,2]$. The products of autoreactive $B$ cells, rheumatoid factor (RF) and recently recognised antibodies against citrullinated peptides are the established markers of severe RA leading to progressive joint destruction, early disability and mortality $[3,4]$. Rituximab, a chimeric monoclonal antibody targeting $B$ cells expressing CD20 antigen, is a prevalent and highly efficient strategy for the treatment of RA when the disease is non-responsive to conventional disease-modifying anti-rheumatic drugs (DMARDs) and anti-TNF $\alpha$ blockade. Treatment with rituximab results in the prolonged alleviation of clinical symptoms of RA and reduction of inflammation [5-8]. Alleviation of clinical symptoms occurs simultaneously with a reduction of autoantibody levels, while the levels of antimicrobial antibodies as well as total levels of immunoglobulins (Ig) do not change $[9,10]$. These observations suggested a selective depletion of a $B$ cell population with potential impact on the pathogenesis of RA.

The expression of CD20 antigen is restricted to the B cell population. It occurs at the early pre-B cell stage of development and remains through out all stages of $B$ cell maturation being down-regulated on plasma blasts/plasma cells. The initial stages of $B$ cell development take place in bone marrow (BM) where autoreactive immature $B$ cells are eliminated by negative selection. The maturation of $B$ cells in $B M$ is characterised by surface expression of $\lg \mathrm{D}$ and $\lg \mathrm{M}$. The mature $\mathrm{B}$ cells that

BM: bone marrow; DAS28: disease activity score; DMARD: disease-modifying antirheumatic drug; ELISA: enzyme-linked immunosorbent assay; ELISPOT: enzyme-linked immunosorbent spot; FACS: Fluorescent Activated Cell Sorting; Ig: immunoglobulins; NSAID: non-steroidal anti-inflammatory drug; PB: peripheral blood; RA: rheumatoid arthritis; RF: rheumatoid factor; TNF: tumor necrosis factor. 
have not been antigen activated (also called antigen naïve) leave BM and migrate via peripheral blood (PB) to secondary lymphoid tissue such as the spleen and lymph nodes. Here they change/switch the expression pattern of $\lg$ from $\lg D$ and $\lg M$ to $\lg G, \lg A$ and $\lg E$. The switch of $\lg$ classes indicates the formation of antigen-specific memory $B$ cells. By the expression of CD27 and $\lg D$, developmental stages of $B$ cells may be identified, as immature $B$ cells ( $C D 27-\lg D^{-}$), naïve $B$ cells $\left(\mathrm{CD} 27-\lg \mathrm{D}^{+}\right)$, un-switched memory $\mathrm{B}$ cells $\left(\mathrm{CD} 27^{+} \lg \mathrm{D}^{+}\right)$and switched memory cells $\left(\mathrm{CD}_{2} 7^{+} \lg \mathrm{D}^{-}\right)$. The population of switched memory B cells may contain even plasma blasts/ cells [11-13]. The expression of CD38 in combination with $\lg D$ may also be used to determine the maturation status on $B$ cells. Due to bi-polar expression of CD38 its intermediate expression characterizes early pre-B cells and transitional cells, and its high expression characterizes end-stage differentiated plasma blasts/cells. To gain more information about the maturation stages of the $\mathrm{B}$ cell population, expression of CD24 and CD10 is usually added [14-25].

The exact subpopulation of B cells targeted and eliminated by rituximab remains uncertain. Several studies investigated the effects of rituximab with respect to its effect on leukocytes in different body compartments and showed an efficient depletion of $B$ cells in circulation, while the number of plasma cells was not changed [26-32]. A reduction of $B$ cells short after rituximab treatment was also observed in synovial tissue $[27,32,33]$. Teng and colleagues [33] showed that $88 \%$ of RA patients had a reduction of $B$ cells in synovium four weeks after treatment and that clinical responders had less infiltration of $\mathrm{CD}_{20}{ }^{+}$and $\mathrm{CD} 138^{+}$cells as compared with poor responders $[27,33]$. Kavanaugh and colleagues [28] also showed that in $80 \%$ of RA patients B cell numbers decreased in synovial tissue eight weeks after rituximab treatment $[27,28]$. Roll and colleagues showed that repopulation of $B$ cells into PB started with $B$ cells expressing CD38 and IgD surface markers, while $\mathrm{CD} 27^{+}$memory $\mathrm{B}$ cells repopulated circulation with a significant delay [30]. Similar pattern of B cell regeneration after rituximab treatment was observed in patients with lymphoma and after autologous stem cell transplantation [29,34]. Leandro and colleagues described a depletion of mature BM B cells three months after rituximab treatment, while pro- and pre-B cells as well as immature $B$ cell population and plasma cells were unaffected in BM; however, no baseline samples were obtained [31]. Teng and colleagues investigated the effect of rituximab in BM and concluded that only 8 of 25 patients with RA showed complete depletion of CD19+ B cells, and no phenotypic data were included [33].

In the present study we used serial samples of BM and PB to prospectively follow the ontogeny of $B$ cells shortly after rituximab treatment and distantly, prior to the follow-up of rituximab treatment. We show that rituximab achieves a depletion of IgD $+B$ cells shortly after the treatment followed by a long-term accumulation of pre-germinal center subsets of $B$ cells in $\mathrm{PB}$ combined with a reduction in switched memory $B$ cells both in $\mathrm{PB}$ and in BM. We showed that the reduction of switched memory $B$ cells $\left(C D 27^{+} \operatorname{lgD}-\right)$ does not prevent repopulation with autoantibody-producing B cell clones.

\section{Materials and methods Patients}

Thirty-seven patients with established RA diagnosed using the American College of Rheumatology criteria [35], were treated with rituximab (monoclonal anti-CD20 antibodies, Mabthera, Hoffman-La Roche Ltd, Basel, Switzerland) at the Rheumatology Clinic at Sahlgrenska University Hospital, Göteborg, Sweden, between January 2007 and May 2008. Table 1 presents clinical and demographic characteristics of the patients and their immunosuppressive treatment. All patients had been treated with TNF $\alpha$ targeting antibodies prior to rituximab. The anti-TNF $\alpha$ treatment was discontinued at least eight weeks before rituximab treatment. During and after rituximab treatment all the patients were on stable-dose NSAID and DMARDs. Rituximab was provided intravenously in two doses of $1000 \mathrm{mg}$ each on days 1 and 15 . The efficacy of rituximab treatment was assessed clinically by disease activity score (DAS) 28, a composite measure based on 28 tender and swollen joint counts, and erythrocyte sedimentation rate. The response to rituximab treatment was evaluated on the basis of European League of Associations for Rheumatology response criteria [36]. The reduction in DAS28 equal to or above 1.2 during the first six months following rituximab treatment was

\section{Table 1}

Clinical and demographic characteristics of patients with rheumatoid arthritis

\begin{tabular}{|c|c|}
\hline & $\begin{array}{l}\text { RA patients } \\
\mathrm{n}=37\end{array}$ \\
\hline Age, years & $53 \pm 10$ \\
\hline (range) & (28-76 years) \\
\hline Sex, male/female & $7 / 30$ \\
\hline Radiological data, erosive/non-erosive & $35 / 2$ \\
\hline Rheumatoid factor, +/- & 33/4 \\
\hline Duration of the disease, years $\pm S D$ & $8 \pm 6$ \\
\hline \multicolumn{2}{|l|}{ Treatment } \\
\hline Methotrexate/other & $35 / 2^{*}$ \\
\hline Previous anti-TNF, yes/no & $37 / 0$ \\
\hline Previous anti-CD20, yes/no & $13 / 24^{\star \star}$ \\
\hline Time after previous anti-CD20, month & $\begin{array}{l}22 \pm 11 \\
\text { (6-61 months) }\end{array}$ \\
\hline \multicolumn{2}{|c|}{$\begin{array}{l}{ }^{*} \text { other, } 1 \text { chlorambucil, } 1 \text { azatioprin. } \\
{ }^{* *} \text { One patient is included in both groups i.e. started as non-treated } \\
\text { then returned and was included as treated. } \\
\text { Values are given as mean } \pm \text { standard deviation (SD). RA = } \\
\text { rheumatoid arthritis. }\end{array}$} \\
\hline
\end{tabular}


Serological characteristics of rheumatoid arthirits patients prior to and following rituximab treatment

\begin{tabular}{|c|c|c|c|c|c|}
\hline & \multicolumn{3}{|c|}{ Bone marrow } & \multicolumn{2}{|c|}{ Peripheral blood } \\
\hline & Baseline & 1 month & 3 months & Baseline & 3 months \\
\hline WBC, $106 / \mathrm{ml}$ & $20.5 \pm 12.6$ & $17.5 \pm 6.5$ & $24.2 \pm 15.9$ & $6.8 \pm 3.0$ & $7.1 \pm 3.2$ \\
\hline CD19+, \% & $5.6 \pm 3.7$ & $1.1 \pm 0.9^{\star \star}$ & $1.6 \pm 1.3^{\star \star}$ & $12.2 \pm 6.4$ & $0^{\star \star \star}$ \\
\hline CD3+, \% & $28.3 \pm 12.7$ & $36.2 \pm 14.3$ & $22.7 \pm 6.2$ & $46.9 \pm 16.2$ & $42.8 \pm 13.9$ \\
\hline CD138+, \% & $0.83 \pm 0.56$ & $0.70 \pm 0.47$ & $0.73 \pm 0.51$ & - & - \\
\hline \multicolumn{6}{|c|}{ ELISPOT, $10^{6}$ lymphocytes $/ \mathrm{ml}$} \\
\hline $\lg G$ & $11073 \pm 11363$ & $10574 \pm 8414$ & $7703 \pm 7451$ & $1504 \pm 3383$ & $427 \pm 800$ \\
\hline $\lg M$ & $8163 \pm 8448$ & $5922 \pm 5492^{\star \star}$ & $4058 \pm 6833$ & $2013 \pm 7070$ & $123 \pm 223$ \\
\hline $\lg A$ & $6009 \pm 4628$ & $7010 \pm 6345$ & $5122 \pm 4015$ & $1280 \pm 2743$ & $471 \pm 1094$ \\
\hline \multicolumn{6}{|l|}{$\mathrm{RF}, \mathrm{U} / \mathrm{ml}$} \\
\hline $\lg G$ & Not assessed & Not assessed & Not assessed & $50 \pm 31$ & $34 \pm 26^{\star \star \star}$ \\
\hline $\lg M$ & Not assessed & Not assessed & Not assessed & $78 \pm 31$ & $64 \pm 49^{\star \star}$ \\
\hline $\lg A$ & Not assessed & Not assessed & Not assessed & $37 \pm 28$ & $30 \pm 25^{\star \star}$ \\
\hline \multicolumn{6}{|c|}{ Total Igs, mg/L } \\
\hline $\lg G$ & Not assessed & Not assessed & Not assessed & $13 \pm 4.5$ & $12.3 \pm 4.2^{\star \star \star}$ \\
\hline $\lg M$ & Not assessed & Not assessed & Not assessed & $1.9 \pm 1.2$ & $1.6 \pm 1.1^{\star \star}$ \\
\hline $\lg A$ & Not assessed & Not assessed & Not assessed & $3.6 \pm 1.8$ & $3.0 \pm 1.3$ \\
\hline
\end{tabular}

${ }^{*} P \leq 0.05 ;{ }^{* \star} P \leq 0.01 ;{ }^{* \star *} P \leq 0.001$

Values are given as mean \pm standard deviation.

$\mathrm{lg}=$ immunoglobulin; $\mathrm{RF}=$ rheumatoid factor; $\mathrm{WBC}=$ white blood cell.

set as the cut-off limit for clinical response. The decision to retreat with rituximab was based on an increase of clinical disease activity in combination with a patient's wish to be treated. The Ethical Committee at the Sahlgrenska Academy at University of Gothenburg approved this study. All patients gave their written informed consent to participate in the study.

\section{Collection of blood and BM samples}

Heparinized blood and BM aspirates of a volume of $10 \mathrm{ml}$ each were obtained at baseline $(n=37)$. Blood and BM sampling was repeated one month (weeks 4 to $6 ; n=10$ ) and three months (weeks 10 to $14 ; n=14$ ) after the first rituximab infusion. $\mathrm{PB}$ and $\mathrm{BM}$ mononuclear cells were isolated by density gradient separation on Lymphoprep (Axis-Shield PoC As, Oslo, Norway).

\section{Flow cytometry}

The cells were prepared and stained for the Fluorescent Activated Cell Sorting (FACS) analysis as previously described $[37,38]$. The non-specific binding was blocked with $0.1 \%$ rabbit serum. The cells were incubated with dye-conjugated monoclonal antibodies (mAbs), washed, resuspended in FACSbuffer (containing PBS, 1\% FCS, 0,1\% NaAz and $0.5 \mathrm{mM}$ EDTA), and submitted to five-colour flow cytometry. From each sample $1 \times 10^{6}-1.5 \times 10^{7}$ lymphocytes were collected in a FACS Canto II equipped with FACS Diva software (BDBioscience, Erebodegem, Belgium). The cells were gated based on the fluorochrome minus one settings when needed [39]. All analyses were performed using the FlowJo software (Three Star Inc., Ashland, OR, USA).

The following monoclonal antibodies were used: anti-CD3 (SK7 or 3K7), anti-CD10 (HI10a), anti-CD19 (HIB19), antiCD24 (ML5), anti-CD27 (LI28), anti-CD38 (HB7) and antiCD138 (Ml15). All the antibodies were purchased from BDBioscience (Erebodegem, Belgium) except for anti-CD19, which were purchased from eBioscience (San Diego, CA, USA). For the Ig analyses we used anti-lgA (F0057), anti-lgD (F0059), anti-IgG (F0056) and anti-lgM (F0058) antibodies (DakoCytomation, Glostrup, Denmark). Polyclonal rabbit $\left.\mathrm{F}(\mathrm{ab})_{2}\right)_{2}$ anti-human Ig was used as isotype control.

\section{Phenotype analysis of $B$ cell populations}

$B$ cells were defined as CD19+CD3- CD27 was used as a memory $B$ cell marker, alone or in combination with $\lg A, \lg D$, $\lg$, and $\lg$. Combination of CD27 and $\lg D$ rendered four different populations: IgD-CD27- (immature B cells), lgD+CD27- (naïve $B$ cells), lgD+CD27+ (unswitched memory 


\section{BM}

(a)

$\lg G$

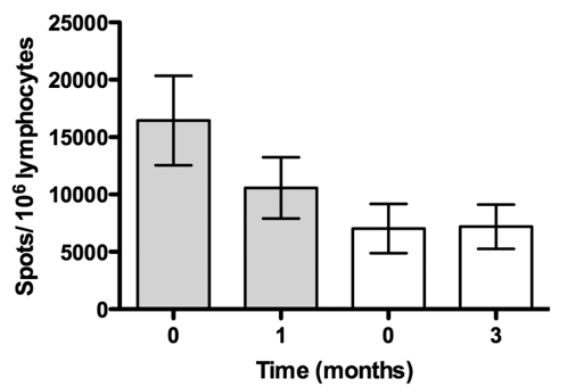

(b)

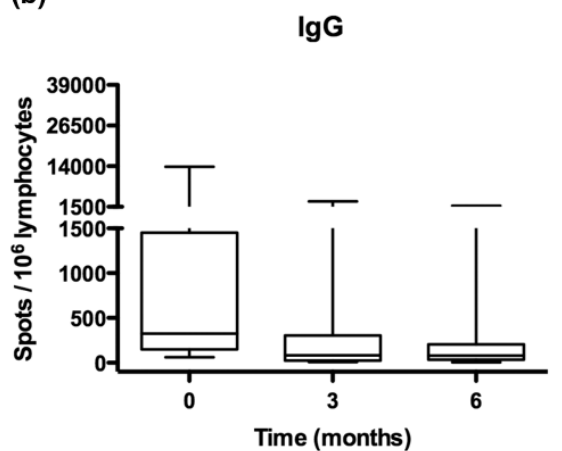

$\lg M$

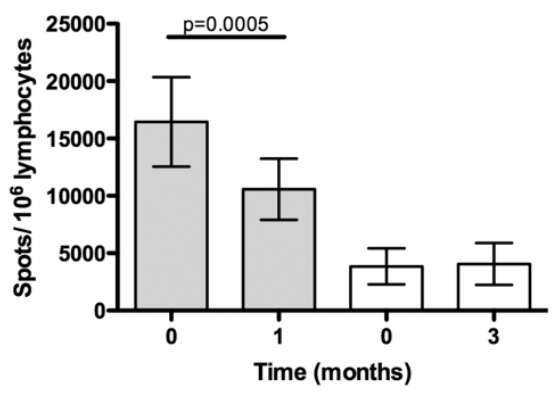

PB

$\lg M$

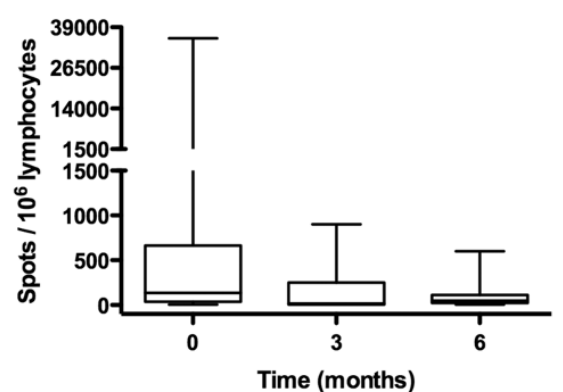

$\lg \mathrm{A}$

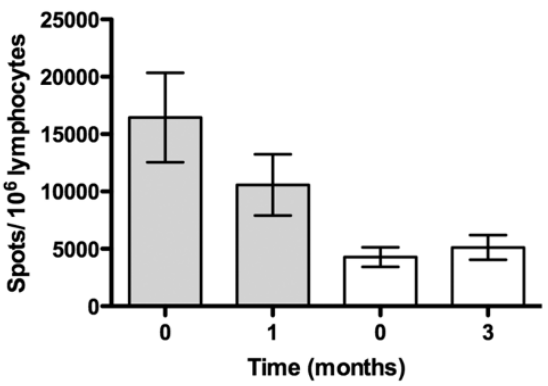

$\lg A$

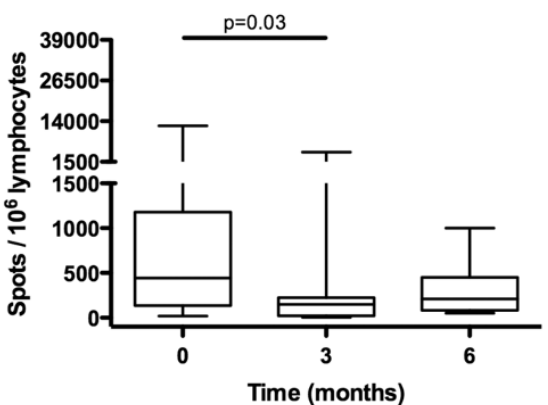

Short-term changes of the Ig-secreting cells in BM and PB after rituximab treatment. (a) Number of immunoglobulin (Ig)-secreting cells in bone marrow (BM) isolated from patients with rheumatoid arthritis at day 0,1 and 3 months after rituximab treatment. Paired with respect to the sampling occasion. Error bars respresenting mean \pm standard error of the mean. (b) Ig-secreting cells in peripheral blood (PB) at day 0, 3 and 6 months after rituximab treatment. Box represents $25^{\text {th }}$ to $75^{\text {th }}$ percentile, line indicates median, whereas error bars represent range. Statistical evaluation was performed using paired t-test.

$B$ cells), and lgD CD27+ (switched memory B cells and plasma blasts/cells) $[40,41]$. The maturation level of the $B$ cell populations was determined using a combination of CD38, CD24, and lgD: CD38++CD24++lgD+/- (immature, transitional, $\mathrm{T} 1$ ), $\mathrm{CD} 38^{+} \lg { }^{+} \lg \mathrm{M}^{++} \mathrm{CD} 24+{ }^{+} \mathrm{CD} 27^{-}$(mature naive $\mathrm{Bm} 2$ ), CD38+lgD-CD24-CD27+ (mature Bm5), and CD38 ${ }^{+++} \operatorname{lgD}{ }^{-}$ D27+ (plasma blasts/cells) [11,42-44]. The first two populations define pre-germinal center B cells, while the last populations consists of post-germinal center B cells.

The mature $B$ cell population (Bm2) is phenotypically close or identical to the naïve $B$ cell population $\left(C D 27 \cdot \lg D^{+}\right)$. To gain more information about immature, pre/pro B cells as well as transitional and germinal center $B$ cell populations, expression of CD10 was also used in combination with CD38 and CD24. Plasma cells were defined as CD138+.

\section{Immunoglobulin secretion}

Secretion of Ig was detected using the enzyme-linked immunosorbent spot (ELISPOT) as described [45]. In short, a 96- well nitrocellulose filter plate (Multiscreen, Millipore, Molsheim, France) was coated with $10 \mu \mathrm{g} / \mathrm{ml}$ goat $F\left(\mathrm{ab}^{\prime}\right)_{2}$ anti-human $\mathrm{lg}$ (Southern Biotech, Birmingham, Alabama, USA). Following blocking, $\mathrm{BM}$ and $\mathrm{PB}$ mononuclear cells were seed in concentrations $1 \times 10^{5}, 2 \times 10^{4}, 4 \times 10^{3}$, and $8 \times 10^{2}$ lymphocytes per well and incubated for 12 hours. Secreted lg were detected using goat anti-human antibodies against $\lg G, \lg A$, and IgM (Sigma-Aldrich, St Louis, Missouri, USA). Each spot corresponds to one lg-secreting $B$ cell. RF of lg-classes $G, A$, and $M$ was measured in serum samples diluted $1 / 100$ by an ELISA (Hycor Biomedical Ltd, Penicuik, Midlothian, UK). Total level of Igs were analysed nephelometrically.

\section{Statistical analyses}

Statistical analysis of changes in the consequent series of samples obtained the same patient was analysed using the paired t-test. For the analysis of the long-term changes the Mann-Whitney test was used. The $P$ value less than 0.05 was considered as significant. All statistical analysis was per- 

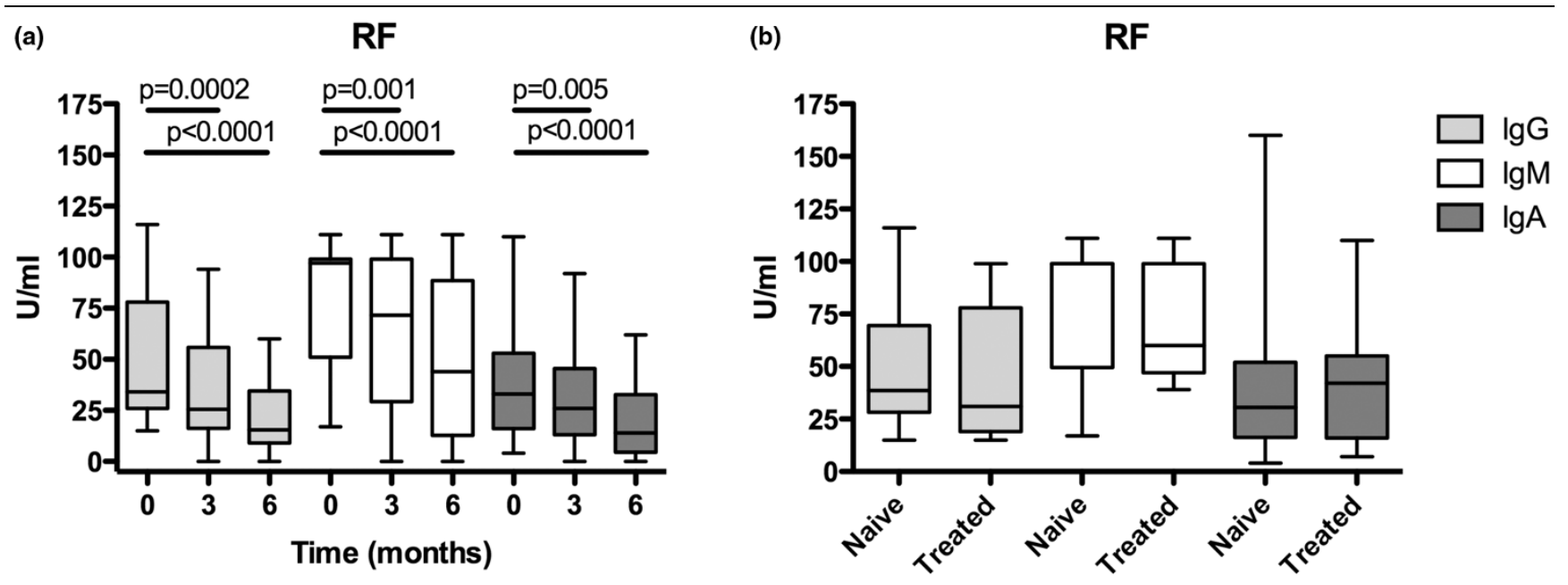

Short- and long-term changes of RF levels in PB after rituximab treatment. (a) Rheumatoid factor (RF)-levels in peripheral blood (PB) at day 0,3 and 6 months after rituximab treatment. (b) RF-levels in PB comparing rituximab-naïve and treated patients. Box represents $25^{\text {th }}$ to $75^{\text {th }}$ percentile, line indicates median, whereas error bars represent range. Statistical evaluation was performed using paired t-test (short-term changes) and Mann-Whitney t-test (long-term changes).

formed using the GraphPad software Prism (GraphPad Software, San Diego, CA, USA).

\section{Results}

\section{Short-term effects of rituximab treatment}

Characteristics of RA patients prior to and following

rituximab treatment

Changes in PB and BM leukocyte populations, Ig, and RF at baseline and following rituximab treatment are presented in Table 2. At baseline, all the patients had $B$ cells defined as CD19+CD3 cells in PB and BM. One and three months after rituximab treatment, $C D 19+C D 3$ - cells were totally eliminated from the PB of all but one patient. In contrast, BM from the same patients analysed at the same time points retained up to $30 \%$ of B cells, which gave a possibility to follow the ontogeny of $B$ cells in the paired samples of BM obtained prior and shortly after rituximab treatment.

Evaluation of $\lg$ secretion in BM using ELISPOT one to three months after rituximab treatment showed a significant decrease of lgM producing cells after one month $(P=0.0005$; Figure 1a). The secretion of $\lg A$ and $\lg G$ in $B M$ was unchanged at all time points. In contrast, a significant decrease of IgA-producing cells $(P=0.03)$ was observed in $\mathrm{PB}$ after three months (Figure 1b). The levels of autoreactive antibodies (RF of $\lg G$, $\lg M$ and $\lg A$ isotypes) in PB were reduced by approximately $50 \%$ (Figure 2 a), while the total levels of circulating lgs were unchanged (not shown).

Analysis of Ig expression on BM B cells using flow cytometry one month $(n=10)$ and three months $(n=14)$ after rituximab treatment revealed a pronounced decrease in frequency of $\lg ^{+}$as well as $\lg \mathrm{M}^{+}$(Figure 3 ). In contrast, the proportion of CD19+CD3- cells expressing surface $\lg A$ and $\lg G$ remained unchanged (Figure 3).

Rituximab depletes immature and naïve $B$ cells in $B M$ To further evaluate the phenotype of $B$ cells escaping rituximab depletion in BM, a combination of CD27 and IgD was used. A representative dot plot is shown in Figure 4. Cumulative results of $B$ cell populations in absolute numbers are given in Table 3. We found a pronounced depletion of naïve $B$ cells $\left(\mathrm{CD} 27 \cdot \operatorname{lgD}{ }^{+}\right)$after one and three months $(P=0.0007$, and $P$ $<0.0001)$. Furthermore, a reduction of immature $B$ cells $\left(\mathrm{CD} 27^{-} \operatorname{lgD} ; P=0.005\right)$ and unswitched $\mathrm{B}$ cells $\left(\mathrm{CD} 27^{+} \lg \mathrm{D}^{+}\right)$ after three months $(P=0.02)$, and switched memory $B$ cells $\left(\mathrm{CD} 2{ }^{+} \operatorname{lgD} ; P=0.01\right)$ after one month was also detected. Importantly, almost all of the $B$ cell populations decreased when analysing absolute numbers as shown in Table 3 . The majority of the surviving $B$ cells was found within the lgD-populations. This argues for a predominant depletion of $\lg D^{+} B$ cells consisting of the naïve and unswitched $B$ cell population. In contrast, switched memory B cells escape depletion despite their surface expression of CD20.

Rituximab treatment results in a total depletion of $C D 38$ expressing $B$ cells in $B M$

The expression of CD38 in combination with $\lg D$ was analysed for further characteristics of $B$ cell maturation in BM shortly after rituximab treatment. A representative dot plot is shown in Figure 5. The absolute numbers of $B$ cells in the defined populations are shown in Table 4. We found a significant reduction of mature $\mathrm{Bm} 2\left(\mathrm{CD}_{3} 8^{+} \operatorname{lgD}{ }^{+} ; P=0.0007, P<0.0001\right.$, at one and three months, respectively) and of $\mathrm{Bm} 5\left(\mathrm{CD} 38^{+} \operatorname{lgD}\right.$; 


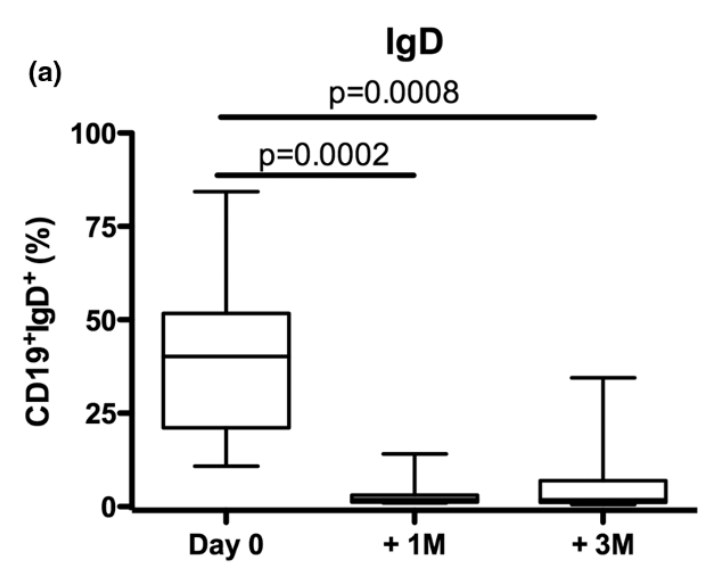

(c)

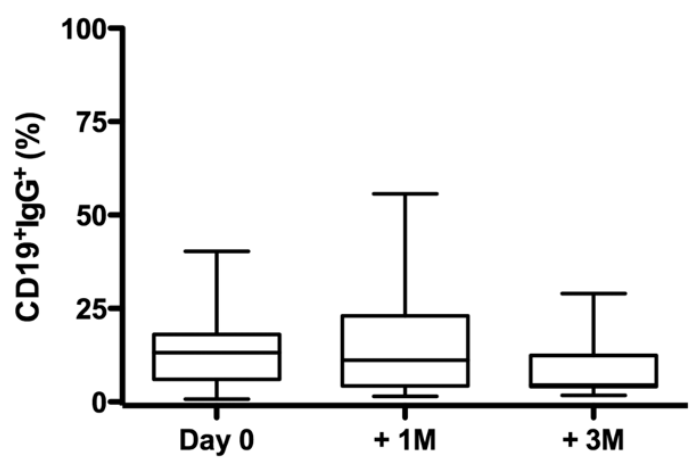

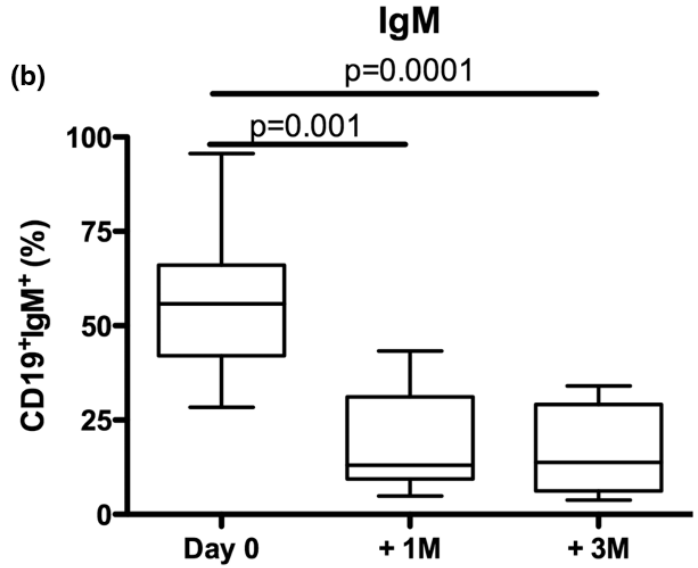

(d)

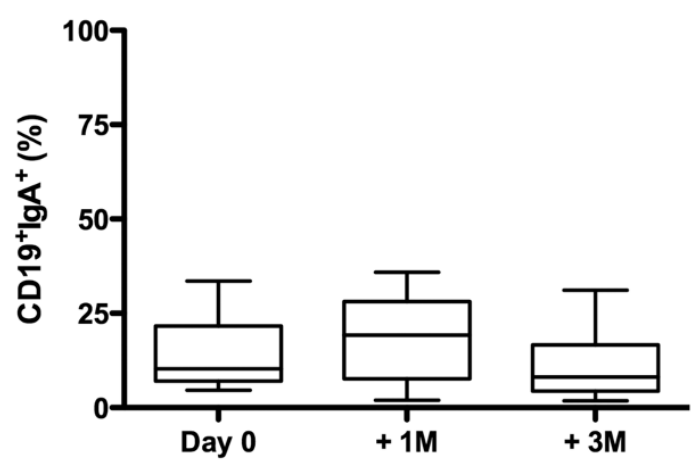

Short-term changes in the immunoglobulin expression of $B$ cells following rituximab treatment. Isolated bone marrow mononuclear cells were stained for immunoglobulin (lg) expression at day 0,1 and 3 months after rituximab treatment. In (a) CD19+ $\operatorname{lgD} D^{+}$, (b) $C^{2} 19^{+} \operatorname{lgM}{ }^{+}$, (c) $\mathrm{CD} 19^{+} \operatorname{lgG}{ }^{+}$and (d) $\mathrm{CD}_{19}{ }^{+} \lg \mathrm{A}^{+}$is shown. Box represents $25^{\text {th }}$ to $75^{\text {th }}$ percentile, line indicates median, whereas error bars represent range. Statistical evaluation was performed using paired t-test.

$P=0.02$, at one month) B cells. The population of immature and transitional (CD38 ${ }^{++}$IgD) $\mathrm{B}$ cells as well as the plasma blasts $\left(\mathrm{CD} 38^{+++} \lg \mathrm{D}^{-}\right)$were not depleted by rituximab treatment. To ascertain the low maturation status of the immature $B$ cells a combination of CD38, CD24, and CD10 was used. The frequency of expression of CD24/CD10 was clearly increased within the remaining $B$ cell population (Figure 5). The analysis of $\mathrm{B}$ cells with respect to CD38 expression shows a predominant depletion of $\mathrm{Bm} 5$ and mature $\mathrm{Bm} 2$. As high expression of CD38 may be characteristic for plasma cells, defined here as $\mathrm{CD}_{138^{+}}$, we analysed the precursors of plasma cells in BM before and after rituximab treatment. No significant changes in plasma cell numbers were observed following rituximab treatment indicating that plasma cells are not affected by rituximab (Table 2 ).

\section{Long-term effects of rituximab treatment}

To evaluate long-term effects of rituximab, we divided the patients into two groups: those who were not treated with rituximab previously, referred to as rituximab-naïve $(n=24)$, and those who had been treated with rituximab previously (mean 22 months, range 6 to 61 months) referred to as rituximab-treated patients $(n=13)$. At admission, these two groups of patients were similar with respect to activity RA (DAS28: $6.00 \pm 0.76$ vs. $5.64 \pm 0.58$, respectively) and the number of $B$ cells in PB and BM (13 $\pm 5 \%$ vs. $11 \pm 4 \%$ ). Analysing the expression of surface-lg on CD19+ BM mononuclear cells showed a decreased frequency of $\lg \mathrm{G}$ and $\lg \mathrm{A}(P=0.003, P$ $=0.001)$ in rituximab-treated patients as compared with rituximab-naïve patients (Figure 6). No differences between the groups were found regarding the expression of $\lg D$ and $\lg M$ (Figure 6). BM from rituximab-treated patients displayed a decrease of lgM-secreting cells as compared with rituximab- 


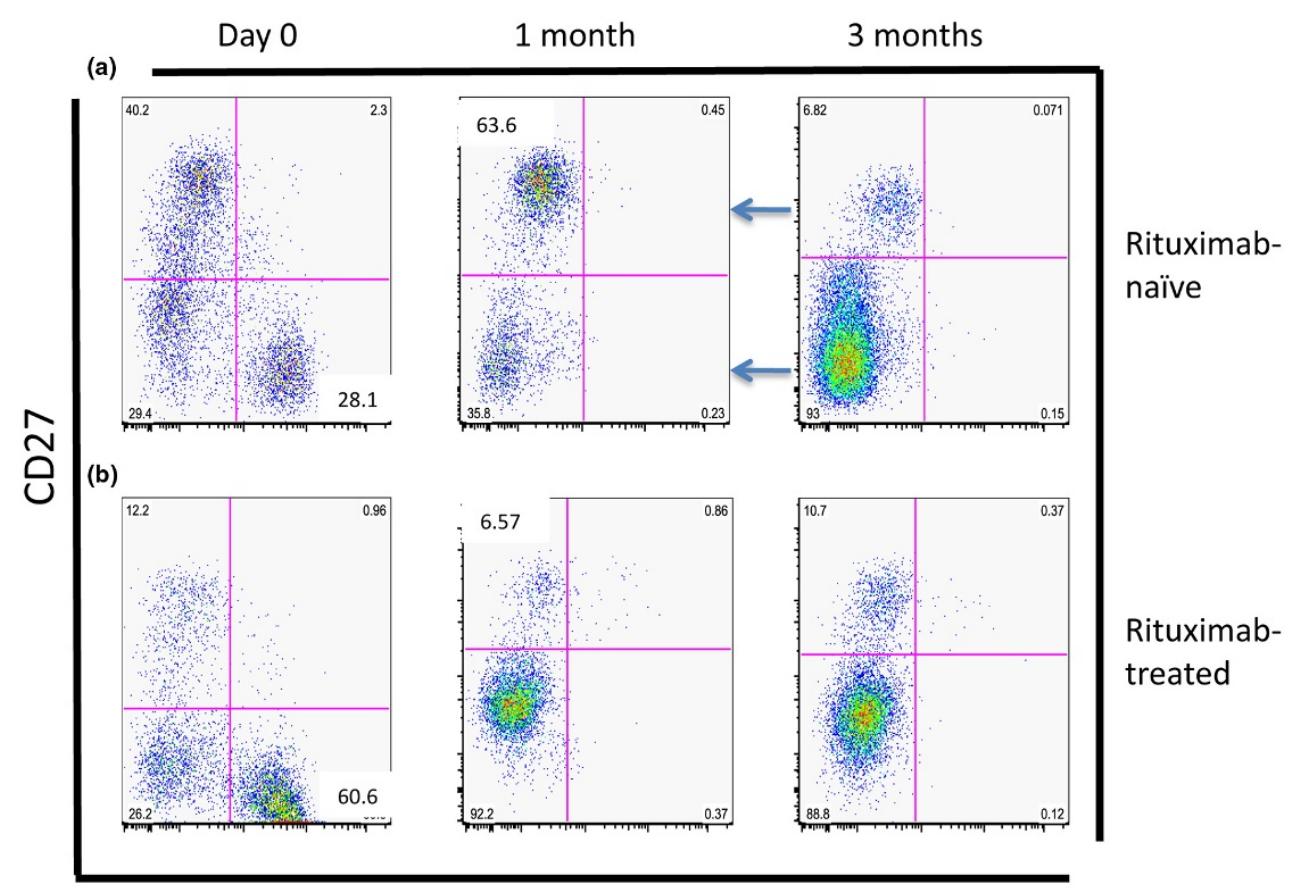

$\lg \mathrm{D}$

A representative plot of short-term and long-term changes of the $B$ cell expression of CD27 and IgD on $B$ cells in bone marrow from patients with rheumatoid arthritis receiving rituximab treatment. Lower left quadrant $=$ immature $B$ cells (IgD-CD27); lower right quadrant $=$ naïve $B$ cells $\left(\lg D^{+} \mathrm{CD} 27\right)$; upper right quadrant $=$ unswitched memory B cells $\left(\lg \mathrm{D}^{+} \mathrm{CD} 27^{+}\right)$; and upper left quadrant $=$switched memory $\mathrm{B}$ cells $\left(\operatorname{lgD}-\mathrm{CD}^{-2} 7^{+}\right)$. (a) Rituximab-naïve patient is shown at day 0,1 month and 3 months following treatment. (b) Rituximab-treated patient is shown at day 0, 1 month and 3 months following treatment. Arrow indicates depleted populations.

naïve patients, while in PB the levels of lg-producing cells were similar (Figure 1a). The levels of total lg levels as well as the circulating RF (Figure 2 b) were similar between the rituximabnaïve and rituximab-treated groups.
Decreased proportion of CD27+ memory $B$ cells in BM and is a hallmark of rituximab treatment

The analysis of CD27 expression in BM showed that rituximabtreated patients had a significantly lower proportion of CD27+ memory B cells $(P=0.0004)$ compared with those who were rituximab naïve (data not shown). This was consequently fol-

Table 3

\section{Absolute numbers of $B$ cells in bone marrow (per $10^{6}$ mononuclear cells)}

\begin{tabular}{|c|c|c|c|c|c|c|c|c|}
\hline & \multicolumn{2}{|c|}{ CD27-IgD- (Immature) } & \multicolumn{2}{|c|}{ CD27-lgD+ (Naïve) } & \multicolumn{2}{|c|}{ CD27+lgD+ (Unswitched) } & \multicolumn{2}{|c|}{ CD27+lgD- (Switched) } \\
\hline & $n=10$ & $\mathrm{n}=14$ & $\mathrm{n}=10$ & $n=14$ & $\mathrm{n}=10$ & $\mathrm{n}=14$ & $\mathrm{n}=10$ & $\mathrm{n}=14$ \\
\hline \multicolumn{9}{|l|}{ Baseline } \\
\hline Day 0 & $134 \pm 100$ & $282 \pm 315$ & $165 \pm 158$ & $213 \pm 116$ & $17 \pm 39$ & $29 \pm 38$ & $70 \pm 48$ & $161 \pm 105$ \\
\hline \multicolumn{9}{|l|}{ Short-term } \\
\hline 1 month & $\begin{array}{c}53 \pm 75 \\
P=0.004\end{array}$ & & $P=\begin{array}{c}4 \pm 4 \\
=0.002\end{array}$ & & $\begin{array}{c}0.5 \pm 0.7 \\
P=0.004\end{array}$ & & $\begin{array}{l}40 \pm 32 \\
P=0.01\end{array}$ & \\
\hline 3 months & & $\begin{array}{c}98 \pm 114 \\
P=\mathrm{ns}\end{array}$ & & $\begin{array}{c}5 \pm 9 \\
P=0.0002\end{array}$ & & $\begin{array}{c}2 \pm 4 \\
P=0.0002\end{array}$ & & $\begin{array}{c}39 \pm 31 \\
P=0.0006\end{array}$ \\
\hline $\begin{array}{l}\text { Post-RTX } \\
\text { survival \% }\end{array}$ & 40 & 35 & 2 & 2 & 3 & 7 & 57 & 24 \\
\hline
\end{tabular}

* Values are given as mean \pm standard deviation.

** Statistics are calculated with paired T-test, $P$-values are given in comparison to day 0 .

$\mathrm{RTX}=$ rituximab. 


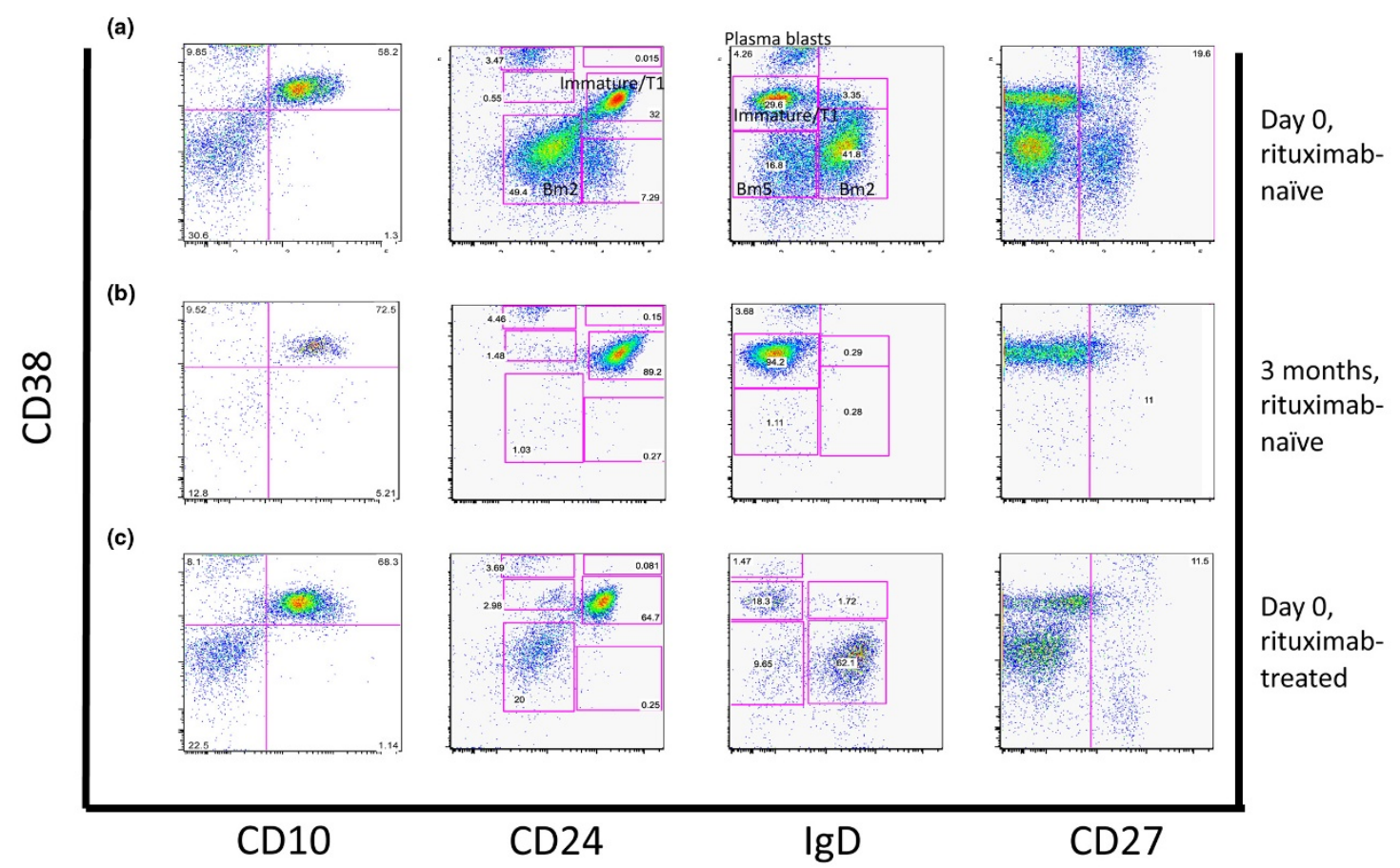

A representative plot of short-term and long-term changes of the B cell expression of CD38 in combination with CD10/CD24/lgD or CD27 in BM from RA patients receiving rituximab treatment. $B$ cells expressing CD38 were analysed with respect to CD10/CD24, IgD or CD27 expression.

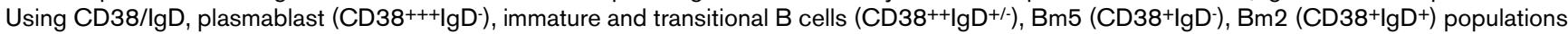
were defined. $\mathrm{B}$ cells from a rituximab-naïve patient at (a) day 0 , (b) after 3 months, and (c) in a rituximab-treated patient at day 0 , is shown for the combination of CD38/CD10/CD24/lgD/CD27.

lowed by a reduction in the unswitched $\left(\mathrm{CD} 27^{+} \lg D^{+}, P<\right.$ $0.0001)$ as well as in the switched memory cells $\left(C D 27+\lg D^{-}\right.$, $P=0.004)$ in $\mathrm{BM}$, and by an increase of immature (CD27-lgD) B cells $(P=0.01)$. The absolute numbers of $\mathrm{B}$ cells in the rituximab-treated and tituximab-naïve patients are shown in Table 5. No correlation was found between the time elapsed after previous rituximab treatment and the amount of immature (CD27-lgD) B cells in BM.

Table 4

Absolute numbers of $B$ cells in bone marrow (per $10^{6}$ mononuclear cells)

\begin{tabular}{|c|c|c|c|c|c|c|c|c|c|c|}
\hline & \multicolumn{2}{|c|}{$\begin{array}{l}\text { CD38+lgD- } \\
(\mathrm{Bm5} 5)\end{array}$} & \multicolumn{2}{|c|}{$\begin{array}{c}\text { CD38+lgD+ } \\
\text { (Mature Bm2) }\end{array}$} & \multicolumn{2}{|c|}{$\begin{array}{l}\text { CD38++lgD- } \\
\text { (Immature/T1) }\end{array}$} & \multicolumn{2}{|c|}{$\begin{array}{c}\text { CD38++lgD+ } \\
\text { (Immature/T1) }\end{array}$} & \multicolumn{2}{|c|}{$\begin{array}{l}\text { CD38+++lgD- } \\
\text { (Plasma blasts) }\end{array}$} \\
\hline & $N=10$ & $\mathrm{n}=14$ & $\mathrm{n}=10$ & $\mathrm{n}=14$ & $\mathrm{n}=10$ & $\mathrm{n}=14$ & $\mathrm{n}=10$ & $\mathrm{n}=14$ & $\mathrm{n}=10$ & $n=14$ \\
\hline \multicolumn{11}{|l|}{ Baseline } \\
\hline Day 0 & $34 \pm 32$ & $55 \pm 51$ & $140 \pm 135$ & $203 \pm 140$ & $96 \pm 98$ & $180 \pm 289$ & $19 \pm 15$ & $35 \pm 49$ & $27 \pm 16$ & $38 \pm 31$ \\
\hline \multicolumn{11}{|l|}{ Short-term } \\
\hline 1 month & $\begin{array}{c}2 \pm 2 \\
P=0.01\end{array}$ & & $\begin{array}{c}0.9 \pm 1 \\
P=0.01\end{array}$ & & $\begin{array}{c}48 \pm 71 \\
P=\mathrm{ns}\end{array}$ & & $\begin{array}{l}9 \pm 25 \\
P=\mathrm{ns}\end{array}$ & & $\begin{array}{c}21 \pm 19 \\
P=\mathrm{ns}\end{array}$ & \\
\hline 3 months & & $\begin{array}{c}12 \pm 32 \\
P=0.04\end{array}$ & & $\begin{array}{c}1 \pm 2 \\
P=0.0001\end{array}$ & & $\begin{array}{c}86 \pm 97 \\
P=\mathrm{ns}\end{array}$ & & $\begin{array}{c}3 \pm 5 \\
P=0.03\end{array}$ & & $\begin{array}{c}23 \pm 29 \\
P=\mathrm{ns}\end{array}$ \\
\hline Post-RTX survival \% & 6 & 22 & 1 & 0.5 & 50 & 48 & 47 & 9 & 78 & 61 \\
\hline
\end{tabular}



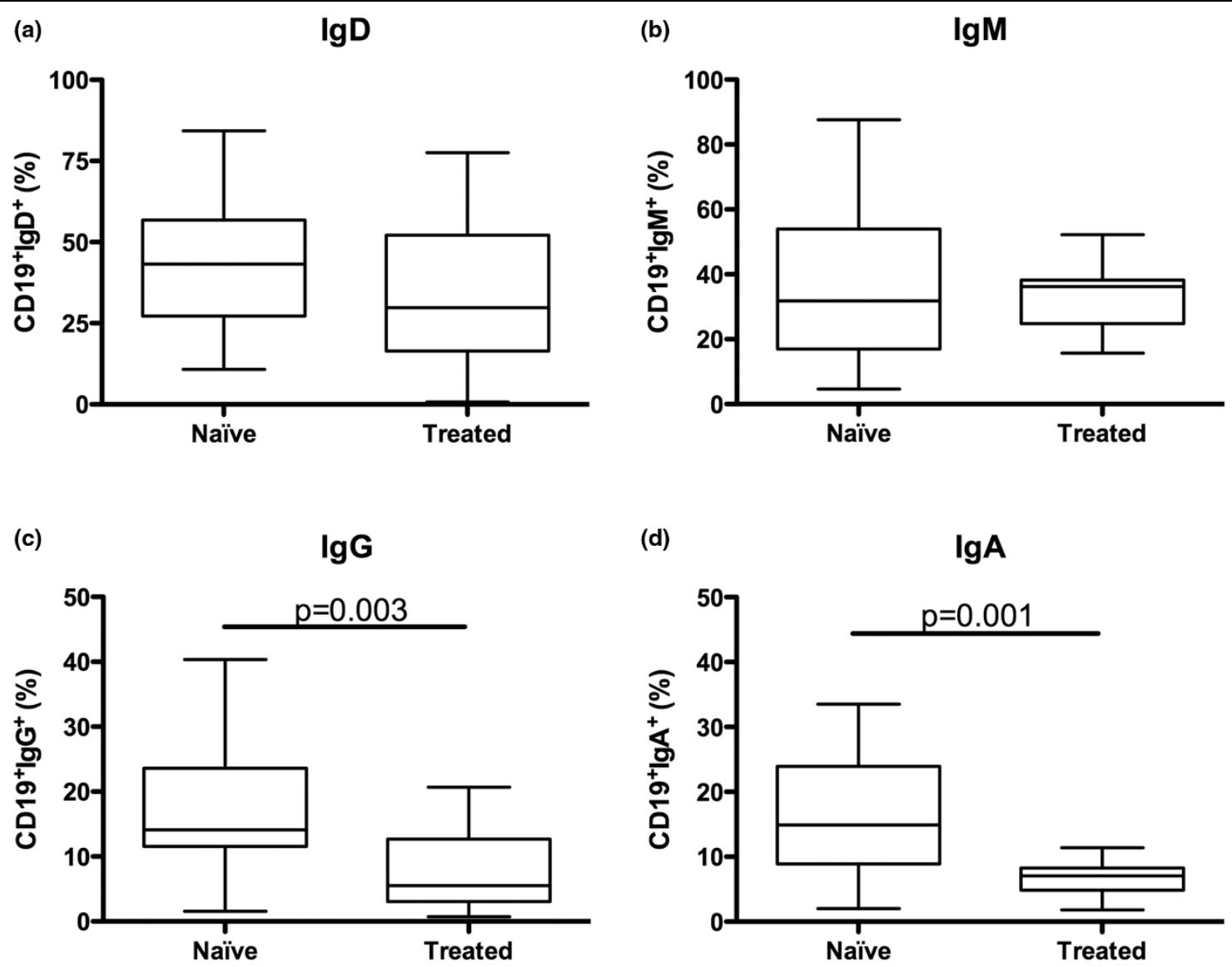

Long-term changes in the immunoglobulin expression of $\mathrm{B}$ cells following rituximab treatment. Isolated bone marrow mononuclear cells were stained for immunoglobulin (lg) expression comparing rituximab-naïve and treated patients. In (a) CD19+ $\lg D^{+}$, (b) $C^{2} 19^{+} \operatorname{lgM}{ }^{+},(\mathbf{c}) \mathrm{CD}^{2} 9^{+} \lg \mathrm{G}^{+}$and (d) $\mathrm{CD} 19^{+} \lg \mathrm{A}^{+}$is shown. Box represents $25^{\text {th }}$ to $75^{\text {th }}$ percentile, line indicates median, whereas error bars represent range. Statistical evaluation was performed using the Mann-Whitney t-test.

Accumulation of immature subset of B cells in BM long after rituximab treatment

We found a proportional increase of immature and transitional (CD38 $\left.{ }^{++} \operatorname{lgD}, P=0.002\right)$ and a reduction of $\mathrm{Bm} 5$ cells $\left(\mathrm{CD} 38^{+} \lg \mathrm{D}^{-}, P<0.0001\right)$ in rituximab-treated patients as compared with rituximab-naïve. The absolute numbers of $B$ cells in the rituximab-treated and rituximab-naïve patients are shown in Table 6. The accumulation of immature subset of $B$ cells in BM of rituximab-treated patients was proved by a prevalence of CD24 expression in immature transitional B cell populations. These findings support our observation on the accumulation of pre-germinal center $B$ cells long after rituximab treatment.

Table 5

Absolute numbers of $B$ cells in bone marrow (per $10^{6}$ mononuclear cells)

\begin{tabular}{|c|c|c|c|c|c|}
\hline Long-term & $\begin{array}{l}\text { CD27-IgD- } \\
\text { (Immature) }\end{array}$ & $\begin{array}{l}\text { CD27-lgD+ } \\
\text { (Naïve) }\end{array}$ & $\begin{array}{c}\mathrm{CD}^{27+\operatorname{lgD}{ }^{+}} \\
\text {(Unswitched) }\end{array}$ & $\begin{array}{l}\text { CD27+lgD- } \\
\text { (Switched) }\end{array}$ & Total number of CD19+ cells \\
\hline $\begin{array}{c}\text { RTX-naïve } \\
n=24\end{array}$ & $\begin{array}{c}185 \pm 247 \\
(32 \%)\end{array}$ & $\begin{array}{c}206 \pm 134 \\
(36 \%)\end{array}$ & $\begin{array}{c}35 \pm 44 \\
(6 \%)\end{array}$ & $\begin{array}{c}148 \pm 94 \\
(26 \%)\end{array}$ & $\begin{array}{l}574 \pm 129 \\
(100 \%)\end{array}$ \\
\hline $\begin{array}{c}\text { RTX-treated } \\
n=13\end{array}$ & $\begin{array}{c}260 \pm 251 \\
(51 \%) \\
P=\mathrm{ns}\end{array}$ & $\begin{array}{c}174 \pm 147 \\
(34 \%) \\
P=\mathrm{ns}\end{array}$ & $\begin{array}{c}4 \pm 3 \\
(1 \%) \\
P=0.0009\end{array}$ & $\begin{array}{c}68 \pm 72 \\
(13 \%) \\
P=0.001\end{array}$ & $\begin{array}{c}506 \pm 118 \\
(100 \%)\end{array}$ \\
\hline
\end{tabular}

* Values are given as mean \pm standard deviation.

** Statistics are calculated with paired T-test, $P$-values are given in comparison to day 0 .

$\mathrm{RTX}=$ rituximab. 
Table 6

\begin{tabular}{|c|c|c|c|c|c|}
\hline Long-term & $\begin{array}{l}\text { CD38+lgD- } \\
(\mathrm{Bm5})\end{array}$ & $\begin{array}{c}\text { CD38+lgD+ } \\
\text { (Mature Bm2) }\end{array}$ & $\begin{array}{l}\text { CD38++lgD- } \\
\text { (Immature/T1) }\end{array}$ & $\begin{array}{c}\text { CD38++lgD+ } \\
\text { (Immature/T1) }\end{array}$ & $\begin{array}{l}\text { CD38+++lgD- } \\
\text { (Plasma blasts) }\end{array}$ \\
\hline $\begin{array}{c}\text { RTX-naïve } \\
n=24\end{array}$ & $75 \pm 54$ & $205 \pm 139$ & $171 \pm 258$ & $39 \pm 51$ & $35 \pm 26$ \\
\hline $\begin{array}{c}\text { RTX-treated } \\
n=13\end{array}$ & $\begin{array}{c}17 \pm 19 \\
P=0.0004\end{array}$ & $\begin{array}{c}155 \pm 134 \\
P=\mathrm{ns}\end{array}$ & $\begin{array}{c}222 \pm 292 \\
P=\mathrm{ns}\end{array}$ & $\begin{array}{c}19 \pm 15 \\
P=\mathrm{ns}\end{array}$ & $\begin{array}{c}22 \pm 18 \\
P=\mathrm{ns}\end{array}$ \\
\hline
\end{tabular}

* Values are given as mean \pm standard deviation.

** Statistics are calculated with paired T-test, $P$-values are given in comparison to day 0 .

$\mathrm{RTX}=$ rituximab.

\section{Discussion}

In the present study we analysed consequences of rituximab treatment on the ontogeny of B cells in BM and in PB shortly after and prior to follow-up rituximab treatment. The short-term changes were characterised by a depletion of naïve and unswitched memory $\mathrm{B}$ cells $\left(\mathrm{IgD}^{+}\right)$as well as $\mathrm{CD}^{+} 8^{+}$populations including mature $\mathrm{Bm} 2\left(\mathrm{CD} 38^{+} \lg \mathrm{D}^{+}\right)$and $\mathrm{Bm} 5 \mathrm{~B}$ cells (CD38+lgD). The long-term changes were characterized by a decrease of the memory $\mathrm{B}$ cell population in BM.

The evaluation of $\mathrm{B}$ cell populations using CD38 marker showed that the switched memory B cells (CD27+lgD-) were preserved in $\mathrm{BM}$ while the pre-germinal center population (Bm2, T1) of B cells were depleted. The short-term changes were characterised by a total depletion of $\lg D+C D 38+B$ cells in $\mathrm{BM}$. The remaining $\mathrm{BM} B$ cell population consists of CD27IgD- immature B cells, and mostly CD27+lgD- switched memory B cells. Simultaneously, the levels of RF and lg-secreting cells in circulation are decreased by $50 \%$ three to six months after rituximab treatment. These data suggest that lgD+CD38+ $B$ cell population or lgM expressing $B$ cell population may be responsible for production of autoreactive Igs. Similar data in $\mathrm{PB}$ are also shown by Koelsch and colleagues [46].

Our findings indicate that switched memory B cells are better survivors of rituximab despite the expected surface expression of CD20. The properties of B cells leading to rituximab resistance and helping $30 \%$ of human BM B cells to escape depletion are elucidated. Similar results were obtained by Teng and colleagues who also showed that rituximab did not achieve a complete depletion of B cells in BM [33]. One of the possible explanations is a lack of or low intensity of CD20 expression on the surface of B cells. Indeed, many B cell precursors and late-stage differentiated $B$ cells (i.e. some plasma blasts/cells) lack CD20 but may express CD19 making them unresponsive to rituximab treatment. We defined $B$ cell population as CD19+, thus discrepancy between CD20 and CD19 expression is difficult to address in our study. It has been shown in animal experiments that the remaining $B$ cells preserved in circulation following rituximab treatment may be memory $B$ cells $[26,47,48]$. Several studies have shown that mature B cells can escape depletion even though they express CD20 [4951]. Another suggested mechanism protecting $B$ cells from depletion with rituximab is the expression of high levels of CD38 and a simultaneous lack of lgD [52-54]. CD38 expressing cells possibly have low levels or a lack of CD20 and this may be a reason for their survival in bone marrow [52-54].

In our group of patients, we used a combination of CD38 and $\lg D$, as a complement to the analysis of CD27 and $\lg D$, to ascertain the maturity stage of $B$ cells and to closer define the $B$ cell population depleted by rituximab. Both ways of $B$ cell analyses show that lgD- population is better preserved after rituximab therapy.

We also showed that the levels of RF are strongly reduced following rituximab treatment, while the total levels of total lgs in circulation remain stable, suggesting: a selective depletion; a depletion of a 'more naïve' B cell population; or a depletion of B cell population potentially responsible for autoantibody secretion.

The long-term follow-up of rituximab effects shows no differences regarding the levels of circulating RFs and lgs in the rituximab-naïve and rituximab-treated patients. This suggests that autoreactive clones of $B$ cells are only temporarily depleted by rituximab while the precursors of autoreactive $B$ cell clones in BM as well as the cells providing signals triggering their development remain unaffected by rituximab. The return of RF into circulation occurred in parallel to the repopulation of naïve ( $\operatorname{lgD}+C D 27-)$ as well as $\operatorname{lgM}+C D 27-B$ cells into $\mathrm{BM}$ and $\mathrm{PB}$ of RA patients admitted for the next course of rituximab treatment. This supports the theory that these B cells may be autoreactive [46]. During the evaluation of distant effects of rituximab, we observed that the development of naïve mature $B$ cells from immature and transitional $B$ cells $\left(\mathrm{CD} 8^{++} \mathrm{IgD}\right)$ remained unaffected. The reduced levels of memory $B$ cells were probably caused by a reduction of postgerminal center Bm5 (CD38+lgD') in PB. One of the explanations for this may be a normal development of immature $B$ cells in BM and an inability of naïve (CD27-) B cells to enter peripheral lymphoid organs or germinal centers resulting in their accumulation in $\mathrm{PB}[30,55]$. Our study is limited to $B$ cell development in the BM, thus we may only speculate about $B$ cell maturation outside the BM, namely in lymph nodes and in germinal centers. Physiological consequences of the inability 
to develop memory cells long after rituximab treatment need further evaluation primarily with respect to changes in antigen presentation and humoral immune responses in RA patients treated with repeated courses of rituximab.

\section{Conclusions}

To conclude, rituximab achieves a depletion of naïve and unswitched B cell populations shortly after the treatment, which is followed by a long-term reduction in switched memory $B$ cells both in PB and in BM. The reduction of switched memory $B$ cells does not prevent repopulation with autoantibody producing $B$ cell clones suggesting that mechanisms regulating the formation of autoreactive clones are not disrupted by rituximab.

\section{Competing interests}

The authors declare that they have no competing interests.

\section{Authors' contributions}

MR performed science, analysed data and wrote paper; SA performed science and analysed data; AT planned science; MIB planned science, collected patient material, analysed data, and wrote paper; MB planned science, performed science, analysed data, and wrote paper.

\section{Acknowledgements}

The work has been supported by the Swedish Medical Society, Medical Society of Göteborg, Swedish Association against Rheumatism, Gothenburg Association against Rheumatism, King Gustaf V:s 80-year Foundation, Swedish Medical Research Council, Nanna Svartz' Foundation, Rune och Ulla Almlövs foundation, Famliy Thölens and Kristlers foundation, National Inflammation Network, the Foundation for Strategic Research, the University of Göteborg, and ROCHE AB Sweden.

\section{References}

1. Takemura S, Klimiuk PA, Braun A, Goronzy JJ, Weyand CM: T cell activation in rheumatoid synovium is $B$ cell dependent. $J$ Immunol 2001, 167:4710-4718.

2. Wipke BT, Wang Z, Nagengast W, Reichert DE, Allen PM: Staging the initiation of autoantibody-induced arthritis: a critical role for immune complexes. J Immuno/ 2004, 172:7694-7702.

3. Drossaers-Bakker KW, de Buck M, van Zeben D, Zwinderman AH, Breedveld FC, Hazes JM: Long-term course and outcome of functional capacity in rheumatoid arthritis: the effect of disease activity and radiologic damage over time. Arthritis Rheum 1999, 42:1854-1860.

4. Tak PP, Bresnihan B: The pathogenesis and prevention of joint damage in rheumatoid arthritis: advances from synovial biopsy and tissue analysis. Arthritis Rheum 2000, 43:2619-2633.

5. Edwards JC, Szczepanski L, Szechinski J, Filipowicz-Sosnowska A, Emery P, Close DR, Stevens RM, Shaw T: Efficacy of B-celltargeted therapy with rituximab in patients with rheumatoid arthritis. N Engl J Med 2004, 350:2572-2581.

6. Emery P, Fleischmann R, Filipowicz-Sosnowska A, Schechtman J, Szczepanski L, Kavanaugh A, Racewicz AJ, van Vollenhoven RF, Li NF, Agarwal S, Hessey EW, Shaw TM: The efficacy and safety of rituximab in patients with active rheumatoid arthritis despite methotrexate treatment: results of a phase IIB randomized, double-blind, placebo-controlled, dose-ranging trial. Arthritis Rheum 2006, 54:1390-1400.

7. Brulhart L, Ciurea A, Finckh A, Notter A, Waldburger JM, Kyburz D, Gabay C: Efficacy of $B$ cell depletion in patients with rheumatoid arthritis refractory to anti-tumour necrosis factor alpha agents: an open-label observational study. Ann Rheum Dis 2006, 65:1255-1257.

8. Cohen SB, Emery P, Greenwald MW, Dougados M, Furie RA Genovese MC, Keystone EC, Loveless JE, Burmester GR, Cravets MW, Hessey EW, Shaw T, Totoritis MC: Rituximab for rheumatoid arthritis refractory to anti-tumor necrosis factor therapy: Results of a multicenter, randomized, double-blind, placebocontrolled, phase III trial evaluating primary efficacy and safety at twenty-four weeks. Arthritis Rheum 2006, 54:2793-2806.

9. Cambridge G, Leandro MJ, Edwards JC, Ehrenstein MR, Salden $M$, Bodman-Smith M, Webster AD: Serologic changes following B lymphocyte depletion therapy for rheumatoid arthritis. Arthritis Rheum 2003, 48:2146-2154.

10. Bokarewa M, Lindholm C, Zendjanchi K, Nadali M, Tarkowski A: Efficacy of anti-CD20 treatment in patients with rheumatoid arthritis resistant to a combination of methotrexate/anti-TNF therapy. Scand J Immunol 2007, 66:476-483.

11. Bohnhorst JO, Bjorgan MB, Thoen JE, Natvig JB, Thompson KM: Bm1-Bm5 classification of peripheral blood $B$ cells reveals circulating germinal center founder cells in healthy individuals and disturbance in the $B$ cell subpopulations in patients with primary Sjogren's syndrome. J Immuno/ 2001, 167:3610-3618.

12. Pers JO, Devauchelle V, Daridon C, Bendaoud B, Le Berre R, Bordron A, Hutin P, Renaudineau Y, Dueymes M, Loisel S, Berthou C, Saraux A, Youinou P: BAFF-modulated repopulation of B lymphocytes in the blood and salivary glands of rituximab-treated patients with Sjogren's syndrome. Arthritis Rheum 2007, 56:1464-1477.

13. Sims GP, Ettinger R, Shirota $Y$, Yarboro $C H$, Illei GG, Lipsky PE: Identification and characterization of circulating human transitional B cells. Blood 2005, 105:4390-4398.

14. Carlsson M, Nilsson K: Reactivity of Workshop B-cell antibodies with B-CLL cells induced to differentiate with or without concommitant proliferation. In leucocyte typing IV Edited by: Knapp W, Dorken B, Gilkes WR, Rieber EP, Stein H, von dem Borne AEGKr. Oxford University Press, Oxford; 1989:206.

15. de Rie MA, Terpstra FG, VanLier RAW, Borne KR Von Dern, Miedema F: Indentification of functional epitopes on Workshopdefined B-cell membrane molecules. In leucocyte typing III Edited by: McMichael AJ, Cobbold S, Crumpton MJ, Gilka W, Peter C. Beverly. Oxford University Press, Oxford; 1987:402.

16. Engel $P$, Ingles J, Gallart T, Vives J: Changes in the expression of B-cell surface antigen detected by the Workshop CD24 monoclonal antibodies following in vitro activation. In leucocyte typing III Edited by: McMichael AJ, Cobbold S, Crumpton MJ, Gilka W, Peter C. Beverly. Oxford University Press, Oxford; 1987:206.

17. Fischer GF, Majdic O, Gadd S, Knapp W: Signal transduction in lymphocytic and myeloid cells via CD24, a new member of phosphoinositol-anchored membrane molecules. J Immunol 1990, 144:638-641.

18. Ling NR, MacLennan CM, Mason DY: B-cell and plasma cell antigens: new and previously defined clusters. In leucocyte typing III Edited by: McMichael AJ, Cobbold S, Crumpton MJ, Gilka W, Peter C. Beverly. Oxford University Press, Oxford: 1987:302.

19. Mittler RS, Talle MA, Carpenter K, Rao PE, Goldstein G: Generation and characterization of monoclonal antibodies reactive with human B lymphocytes. J Immunol 1983, 131:1754-1761.

20. Pezzutto ABF, Callard RE, Clark EA, Genetet N, Goodahl AH, Gramatzki M, Hostoffer P, Cooper MD, Heldrup J, Campana D, Janossy G, Ling NR, Ledbetter JA, Ludwig WD, Pilkington GR, Steel CM, Tedder TF, Wijdenes J, Racadoet E, Dörken B: Flow Cytometry analysis of the B-cell blind panel: joint report. In leucocyte typing IV Edited by: Knapp W, Dorken B, Gilkes WR, Rieber EP, Stein $\mathrm{H}$, von dem Borne AEGKr. Oxford University Press, Oxford; 1989:165.

21. Rabinovitch PS, Clark EA, Pezzutto A, Ledbetter JA, Draves KE: Modulation of human B-cell activation by Workshop monoclonal antibodies to B-cell associated differentiation antigens. In leucocyte typing III Edited by: McMichael AJ, Cobbold S, Crumpton MJ, Gilka W, Peter C. Beverly. Oxford University Press, Oxford; 1987:435.

22. Rawle FC, Armitage RJ, lliescu V, Timms EM, Beverley PCL: Functional role of $\mathrm{B}$-cell surface antigens. In leucocyte typing III Edited by: McMichael AJ, Cobbold S, Crumpton MJ, Gilka W, Peter C. Beverly. Oxford University Press, Oxford; 1987:448. 
23. Shields JG, Smith SH, Callard RE: Modulation in responses to human B-cell growth and differentiation factors with monoclonal antibodies to B-cells surface antigens. In leucocyte typing II/ Edited by: McMichael AJ, Cobbold S, Crumpton MJ, Gilka W, Peter C. Beverly. Oxford University Press, Oxford; 1987:448.

24. Wang CY, Azzo W, Al-Katib A, Chiorazzi N, Knowles DM 2nd: Preparation and characterization of monoclonal antibodies recognizing three distinct differentiation antigens (BL1, BL2, BL3) on human B lymphocytes. J Immunol 1984, 133:684-691.

25. Marie-Cardine A, Divay F, Dutot I, Green A, Perdrix A, Boyer O, Contentin N, Tilly H, Tron F, Vannier JP, Jacquot S: Transitional B cells in humans: characterization and insight from B lymphocyte reconstitution after hematopoietic stem cell transplantation. Clin Immunol 2008, 127:14-25.

26. Uchida J, Hamaguchi Y, Oliver JA, Ravetch JV, Poe JC, Haas KM, Tedder TF: The innate mononuclear phagocyte network depletes B lymphocytes through Fc receptor-dependent mechanisms during anti-CD20 antibody immunotherapy. J Exp Med 2004, 199:1659-1669.

27. Vos K, Thurlings RM, Wijbrandts CA, van Schaardenburg D, Gerlag DM, Tak PP: Early effects of rituximab on the synovial cell infiltrate in patients with rheumatoid arthritis. Arthritis Rheum 2007, 56:772-778.

28. Kavanaugh A, Rosengren S, Lee SJ, Hammaker D, Firestein GS, Kalunian K, Wei N, Boyle DL: Assessment of rituximab's immunomodulatory synovial effects (ARISE trial). 1: clinical and synovial biomarker results. Ann Rheum Dis 2008, 67:402-408.

29. Anolik JH, Friedberg JW, Zheng B, Barnard J, Owen T, Cushing E, Kelly J, Milner EC, Fisher RI, Sanz I: B cell reconstitution after rituximab treatment of lymphoma recapitulates B cell ontogeny. Clin Immunol 2007, 122:139-145.

30. Roll P, Palanichamy A, Kneitz C, Dorner T, Tony HP: Regeneration of $B$ cell subsets after transient $B$ cell depletion using antiCD20 antibodies in rheumatoid arthritis. Arthritis Rheum 2006, 54:2377-2386.

31. Leandro MJ, Cooper N, Cambridge G, Ehrenstein MR, Edwards JC: Bone marrow B-lineage cells in patients with rheumatoid arthritis following rituximab therapy. Rheumatology (Oxford) 2007, 46:29-36.

32. Thurlings RM, Vos K, Wijbrandts CA, Zwinderman A, Gerlag DM, Tak PP: Synovial tissue response to rituximab: mechanism of action and identification of biomarkers of response. Ann Rheum Dis 2007.

33. Teng YK, Levarht EW, Hashemi M, Bajema IM, Toes RE, Huizinga TW, van Laar JM: Immunohistochemical analysis as a means to predict responsiveness to rituximab treatment. Arthritis Rheum 2007, 56:3909-3918.

34. Avanzini MA, Locatelli F, Dos Santos C, Maccario R, Lenta E, Oliveri M, Giebel S, De Stefano P, Rossi F, Giorgiani G, Amendola G, Telli S, Marconi M: B Iymphocyte reconstitution after hematopoietic stem cell transplantation: functional immaturity and slow recovery of memory CD27+ B cells. Exp Hematol 2005, 33:480-486.

35. Arnett FC, Edworthy SM, Bloch DA, McShane DJ, Fries JF, Cooper NS, Healey LA, Kaplan SR, Liang MH, Luthra HSTAM Jr, Mitchell DM, Neustadt DH, Pinals RS, Schaller JG, Sharp JT, Wilder RL, Hunder GG: The American Rheumatism Association 1987 revised criteria for the classification of rheumatoid arthritis. Arthritis Rheum 1988, 31:315-324.

36. van Gestel AM, Anderson JJ, van Riel PL, Boers M, Haagsma CJ, Rich B, Wells G, Lange ML, Felson DT: ACR and EULAR improvement criteria have comparable validity in rheumatoid arthritis trials. American College of Rheumatology European League of Associations for Rheumatology. J Rheumatol 1999, 26:705-711.

37. Amu S, Stromberg K, Bokarewa M, Tarkowski A, Brisslert M: CD25-expressing B-lymphocytes in rheumatic diseases. Scand J Immunol 2007, 65:182-191.

38. Amu S, Tarkowski A, Dorner T, Bokarewa M, Brisslert M: The Human Immunomodulatory CD25(+) B Cell Population belongs to the Memory B Cell Pool. Scand J Immunol 2007, 66:77-86

39. Perfetto SP, Chattopadhyay PK, Roederer M: Seventeen-colour flow cytometry: unravelling the immune system. Nat Rev Immunol 2004, 4:648-655.

40. Roll P, Dorner T, Tony HP: Anti-CD20 therapy in patients with rheumatoid arthritis: predictors of response and $B$ cell subset regeneration after repeated treatment. Arthritis Rheum 2008, 58:1566-1575.

41. Sanz I, Wei C, Lee FE, Anolik J: Phenotypic and functional heterogeneity of human memory B cells. Semin Immunol 2008 , 20:67-82.

42. Binard A, Le Pottier L, Devauchelle-Pensec V, Saraux A, Youinou $P$, Pers JO: Is the blood B-cell subset profile diagnostic for Sjogren syndrome? Ann Rheum Dis 2009, 68:1447-1452.

43. Pascual V, Liu YJ, Magalski A, de Bouteiller O, Banchereau J, Capra JD: Analysis of somatic mutation in five $B$ cell subsets of human tonsil. J Exp Med 1994, 180:329-339.

44. Vugmeyster Y, Howell K, Bakshi A, Flores C, Hwang O, McKeever $\mathrm{K}$ : B-cell subsets in blood and lymphoid organs in Macaca fascicularis. Cytometry $A$ 2004, 61:69-75.

45. Czerkinsky CC, Nilsson LA, Nygren H, Ouchterlony O, Tarkowski A: A solid-phase enzyme-linked immunospot (ELISPOT) assay for enumeration of specific antibody-secreting cells. J Immunol Methods 1983, 65:109-121.

46. Koelsch K, Zheng NY, Zhang Q, Duty A, Helms C, Mathias MD, Jared M, Smith K, Capra JD, Wilson PC: Mature B cells class switched to IgD are autoreactive in healthy individuals. J Clin Invest 2007, 117:1558-1565.

47. Gong Q, Ou Q, Ye S, Lee WP, Cornelius J, Diehl L, Lin WY, Hu Z, Lu Y, Chen Y, Wu Y, Meng YG, Gribling P, Lin Z, Nguyen K, Tran T, Zhang $Y$, Rosen H, Martin F, Chan AC: Importance of cellular microenvironment and circulatory dynamics in $B$ cell immunotherapy. J Immunol 2005, 174:817-826.

48. Hamaguchi Y, Uchida J, Cain DW, Venturi GM, Poe JC, Haas KM, Tedder TF: The peritoneal cavity provides a protective niche for B1 and conventional B lymphocytes during anti-CD20 immunotherapy in mice. J Immunol 2005, 174:4389-4399.

49. Martin F, Chan AC: B cell immunobiology in disease: evolving concepts from the clinic. Annu Rev Immunol 2006, 24:467-496.

50. Schroder C, Azimzadeh AM, Wu G, Price JO, Atkinson JB, Pierson RN: Anti-CD20 treatment depletes B-cells in blood and lymphatic tissue of cynomolgus monkeys. Transpl Immuno/ 2003, 12:19-28.

51. Vugmeyster $Y$, Beyer J, Howell K, Combs D, Fielder P, Yang J, Qureshi F, Sandlund B, Kawaguchi L, Dummer W, Lowman H, McKeever K: Depletion of B cells by a humanized anti-CD20 antibody PRO70769 in Macaca fascicularis. $J$ Immunother 2005, 28:212-219.

52. Lucio $P$, Parreira $A$, Beemd $M W$ van den, van Lochem $E G$, van Wering ER, Baars E, Porwit-MacDonald A, Bjorklund E, Gaipa G, Biondi A, Orfao A, Janossy G, van Dongen JJ, San Miguel JF: Flow cytometric analysis of normal $B$ cell differentiation: a frame of reference for the detection of minimal residual disease in precursor-B-ALL. Leukemia 1999, 13:419-427.

53. McKenna RW, Washington LT, Aquino DB, Picker LJ, Kroft SH: Immunophenotypic analysis of hematogones (B-lymphocyte precursors) in 662 consecutive bone marrow specimens by 4color flow cytometry. Blood 2001, 98:2498-2507.

54. Reff ME, Carner K, Chambers KS, Chinn PC, Leonard JE, Raab R, Newman RA, Hanna N, Anderson DR: Depletion of B cells in vivo by a chimeric mouse human monoclonal antibody to CD20. Blood 1994, 83:435-445.

55. Sidner RA, Book BK, Agarwal A, Bearden CM, Vieira CA, Pescovitz $M D$ : In vivo human $B$-cell subset recovery after in vivo depletion with rituximab, anti-human CD20 monoclonal antibody. Hum Antibodies 2004, 13:55-62. 